УДК 339.9

DOI 10.31554/978-5-7925-0605-3-2021-55-58

\author{
ВНЕШНЕЭКОНОМИЧЕСКИЕ ОТНОШЕНИЯ РОССИИ И МОНГОЛИИ \\ В УСЛОВИЯХ НОВОЙ МИРОВОЙ ГЕОПОЛИТИКИ \\ Шаралдаев Б.Б. ${ }^{1}$,Шаралдаева И.А. ${ }^{2}$ \\ ${ }^{1}$ Байкальский институт природопользования СО РАН, Улан-Удэ, Россия \\ bbsh2016@mail.ru \\ ${ }^{2}$ Восточно-Сибирский государственный университет технологий и управления, Улан-Удэ, Россия \\ sharaldaeva_ia@mail.ru
}

\title{
FOREIGN ECONOMIC RELATIONS OF RUSSIA AND MONGOLIA IN THE CONDITIONS OF THE NEW WORLD GEOPOLITICS Sharaldaev B.B. ${ }^{1}$, Sharaldaeva I.A. ${ }^{2}$ \\ ${ }^{1}$ Baikal Institute of Nature Management SB RAS, Ulan-Ude, Russia; ${ }^{2}$ East Siberian State University of Technology and Management, Ulan-Ude, Russia
}

В данной статье исследованы проблемы и перспективы внешнеэкономического отношения России и Монголии в современных условиях новой мировой геополитики. А также влияние на экономическое положение введенных санкции ведущих стран мира, исследованы причины роста и спада товарооборота, рассмотрены доли Монголии во внешнеэкономической деятельности и товарообороте России. Кроме того, рассмотрена проблема товарооборота в условиях ограничений из-за пандемии. Исследования показали, что введенные санкции и всемирная пандемия серьезно повлияли на экономические отношения России и Монголии.

Ключевые слова: товарооборот, санкции, граница, экономические отношения, мировая геополитика, пандемия, внешнеэкономическая деятельность.

This article examines the problems and prospects of foreign economic relations between Russia and Mongolia in the modern conditions of the new world geopolitics. As well as the impact on the economic situation of the imposed sanctions of the leading countries of the world, the reasons for the growth and decline of trade turnover are investigated, in addition, the share of Mongolia in foreign economic activity and trade turnover of Russia is also considered. In addition, the problem of trade turnover in conditions of restrictions due to a pandemic is considered. Studies have shown that the imposed sanctions and the global pandemic have seriously affected the economic relations between Russia and Mongolia.

Keywords: turnover, sanctions, border, economic relations, world geopolitics, pandemic, foreign economic activity.

В современных условиях быстро меняющейся новой мировой геополитики влияющей в целом на все государства, особенно со слаборазвитой экономикой. Как практика показывает, социальноэкономическая система слаборазвитых стран оказывается достаточно чувствительной к разным политическим, экономическим и другим явлениям государственных решений ведущих стран мира. В данном случае влияние торговой войны между Китаем и США, крайне сложные политические и экономические отношения Российской Федерации и США, безусловно, отражаются на внешнеэкономической деятельности Монголии, в связи с тем, что Российская Федерация и Китай являются ведущими партнерами во внешнеэкономической деятельности Монголии. Учитывая, что Япония и Южная Корея имеют большие экономические интересы и, как следствие, данные страны выделяют Монголии большие инвестиции.

Таким образом, Монголию вынуждают на более осторожные отношения с Россией и Китаем. Если рассмотрим географическое расположение Монголии, то Россия и Китай являются сопредельными государствами, поэтому Правительство Монголии вынуждены вести достаточно гибкую международную политику и со странами, объявившими России санкции [1], и с Китаем, который является дружественным партнером России. 
Однако, в дальнейшем исследовании рассмотрим, внешнеэкономические отношения России и Монголии начиная со времен введения санкции [2] против России и влияние пандемии [3]. В этом году исполняется 100 лет сотрудничества молодой Советской России и Монголии.

В данном исследовании, рассмотрим торговые отношения России и Монголии за последние годы начиная с 2014-2020 гг. [5]. За рассматриваемый период в данном исследовании наблюдаем резкое изменение мировой геополитики, которое по-разному повлияло на мировое сообщество, в принятие политических и экономических решении в интересах своего государства и в интересах стран партнеров.

На рис. 1 представлен товарооборот Монголии и России.

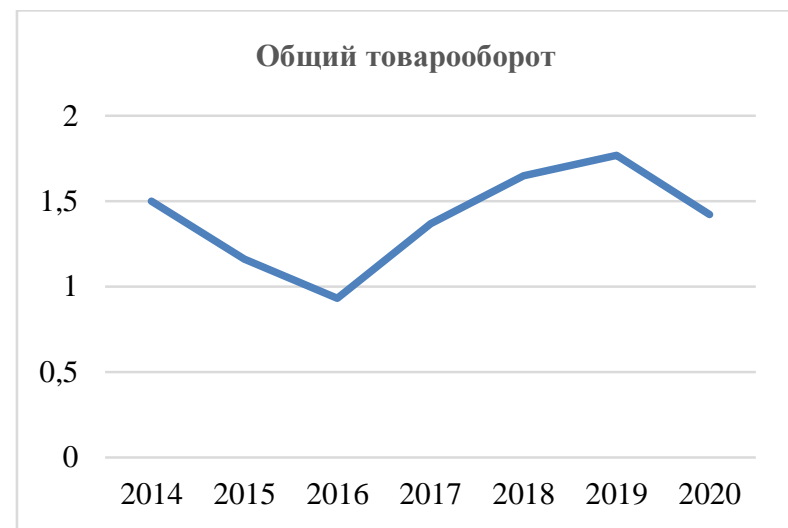

Рис. 1. Товарооборот Монголии и России

Анализ показывает, что санкции, введенные против Российской Федерации ведущими странами мира, достаточно серьезно повлияли на экономические отношения России и Монголии. Например, если в 2014 г. товарооборот составил 1,5 млрд. долларов США, то в 2016 г. составил всего 931 млн. долларов США, что составил всего $62,07 \%$ к 2014 г. или спад составил $37,92 \%$. На рис. 2 представлен экспорт и импорт России в Монголию. Из анализа представленного рисунка видно, что в 2014 г. экспорт составил 1,46 млрд. долларов США, а в 2016 г. - 0,895 млрд. долларов США, что к 2014 г. всего 61,3\%, таким образом произошел спад на $38,7 \%$.

Анализируя импорт, можно сделать следующий вывод, что в 2014 г. Россия вывезла товаров из Монголии на сумму 0,04 млрд. долларов США, а в 2016 г. импорт составил 0,035 млрд. долларов США и спад составил 18,0 \%. Безусловно, Монголия по отношению к России приняла сдерживающее решение, если не считать большего, что Монголия поддержало санкции, введенные против Российской Федерации. Учитывая, что основным сложным годом является 2016 г., а 2014 г. представляет наиболее высокие показатели, поэтому рассмотрим изменение структуры товаров экспорта России в Монголию. На рис. 3 представлена структура экспорта товаров России в Монголию за 2016 г.
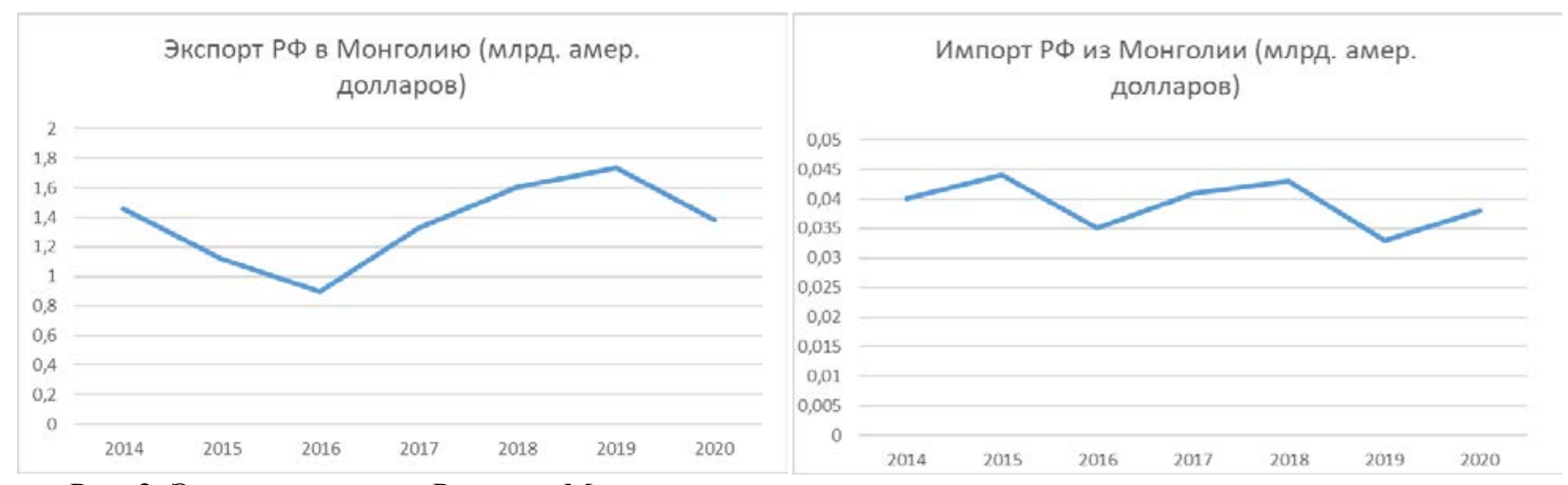

Рис. 2. Экспорт и импорт России в Монголию

Из анализа рис. 3 видно, что ассортимент основных товаров, поставляемых в Монголию незначительный. Основным товаром являются продукты переработки нефти, что составило 62,0 \% от общего объема экспорта, вторым по значимости являются продовольственные товары и сельскохозяйственное сырье - 19,0 \%. Машины, оборудование и транспортные средства, а также продукция химической промышленности соответственно составили 9,0 \% и 7,0 \%, металлы и изделия из них - 3,0 \%.

По показателям внешнеэкономической деятельности 2014 г. является наиболее успешным и рис. 4 представлена структура экспорта товаров России в Монголию. 


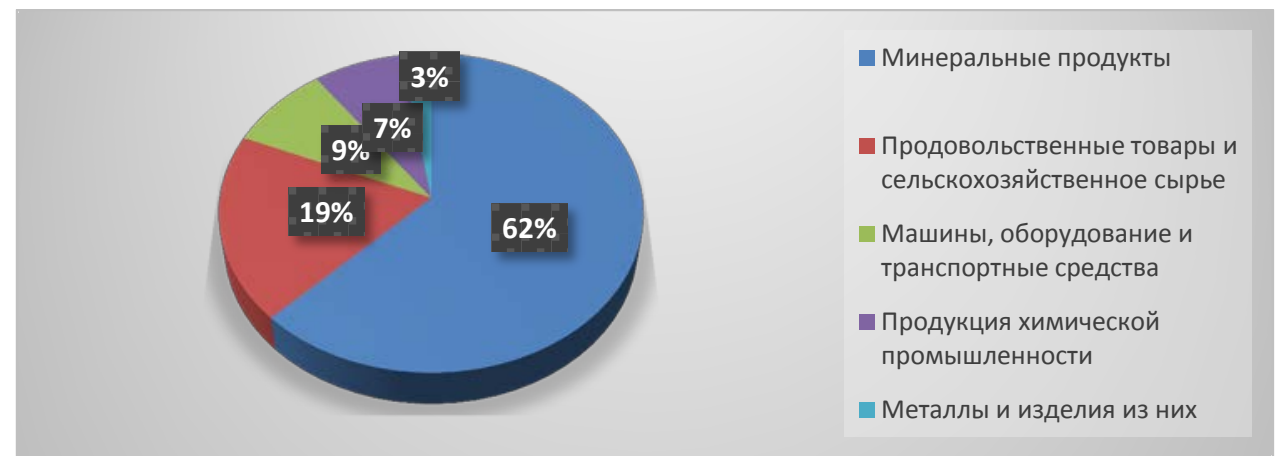

Рис. 3. Структура экспорта товара России в Монголию за 2016 г.

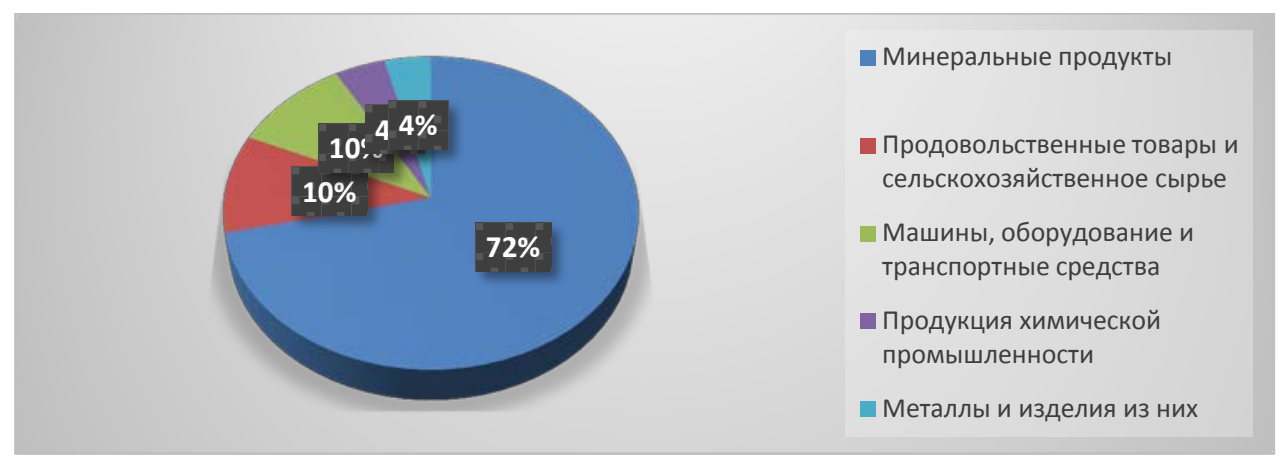

Рис. 4. Структура экспорта товара России в Монголию за 2014 г.

Анализ рис. 3 и 4 наглядно показывает, что спад экспорта нефти и продуктов его переработки составил $10,0 \%$. Также наблюдается незначительный спад продукции химической промышленности на 3,0\%. Экспорт продовольственных товаров и сельскохозяйственного сырья увеличился на $9 \%$, машины, оборудования и транспортных средств, металлов и изделий - на 1,0 \%. Таким образом, анализа экспорта товаров позволил установить, что наиболее серьезный спад экспорта произошел в следующих товарах, нефти и продуктов ее переработки - 10,0 \%, продукции химической промышленности $-3,0 \%$.

На современную систему государственного управления на мировом уровне огромное влияние оказала пандемия, начавшаяся в конце 2019 г. [4]. Учитывая, что Монголия одна из первых закрыла границу, естественно произошел спад товарооборота между нашими странами. Очевидно, что для определения, насколько повлиял данный фактор, как пандемия на торгово-экономические отношения наших стран, авторы считают, что для этого необходимо сравнить годовые показатели 2019 г. с показателями 2020 г. Из рис. 1 видно, что с 2016 г. идет стабильный устойчивый рост товарооборота между нашими странами. В связи, с чем авторами исходным годом для исследования принят 2019 г., так как в этом году товарооборот достиг максимальных показателей. За последние десять лет мировое сообщество, и особенно Российская Федерация, прошли через ряд крупных событий: мировой финансовый кризис 2008 г.; введение санкции против России в 2014 г. ведущими экономическими странами; в 2020 г. весь мир потрясла пандемия.

Сравнительный анализ показал, что товарооборот в 2019 г. составил 1,768 млрд. долларов США, а в 2020 г. - 1,421 млрд. долларов США, что всего 80,38 \% по отношению к 2019 г. или иными словами товарооборот сократился на 19,62 \%. Экспорт в 2020 г. составил 1,383 млрд. долларов США, что к 2019 г. всего 80,0 \%, то есть сократился на 20,0\%. Импорт в 2020 г. составил 0,038 млрд. долларов США, по отношению к 2019 г. рост составил 13,0\%.

Таким образом, результаты исследования показали, что влияние введенных санкций против Российской Федерации, безусловно, значительно повлияли на внешнеэкономические отношения с Монголией. Спад товарооборота составил почти 40,0\%. Влияние на торгово-экономические отношения между нашими странами пандемии относительно санкций незначительно и, тем более если взять исходным годом для расчета 2014 г., то спад составил всего 5,0 \%. В связи, с чем можно считать, что санкции, введенные ведущими экономическими державами, серьезно повлияли на торговоэкономические отношения России и Монголии. 
Работа выполнена в рамках бюджетного проекта БИП СО РАН «Роль Азиатской России и сопредельных территорий в пространственном развитии страны в современных геополитических условиях》 (№ AAAA-A19119060390027-8).

\section{Список литературы}

1. Вице-президент США: страны ЕС пошли на введение санкций против РФ под давлением Вашингтона // TACC, 3.10.2014. URL: https://tass.ru/mezhdunarodnaya-panorama/1483693 (дата обращения: 30.05.20121)

2. Керри: США пока не вводят санкций против России ради возможности вести диалог ИТАР-ТАСС, 07.03.14. URL: https://tass.ru/mezhdunarodnaya-panorama/1027488 (дата обращения: 30.05.2021)

3. Chaolin Huang, Yeming Wang, Xingwang Li, Lili Ren, Jianping Zhao. Clinical features of patients infected with 2019 novel coronavirus in Wuhan, China (англ.) // The Lancet. Elsevier. 2020. Vol. 395, Iss. 10223. pp. $497-506$. - ISSN 1474-547X 0140-6736, 1474-547X. doi:10.1016/S0140-6736(20)30183-5

4. Заявление по итогам второго совещания Комитета по чрезвычайной ситуации в соответствии с Международными медико-санитарными правилами, в связи со вспышкой заболевания, вызванного новым коронавирусом 2019 г. (nCoV). Всемирная организация здравоохранения (30 января 2020). URL: https://www.who.int/ ru/news/item/30-01-2020-statement-on-the-second-meeting-of-the-international-health-regulations-(2005)-emergencycommittee-regarding-the-outbreak-of-novel-coronavirus-(2019-ncov) (дата обращения: 16.07.2020).

5. RU - Stat: Экспорт и импорт России по товарам и странам: 2014 - 2020 гг. 